\title{
Switching to three pre-meal injections of insulin glulisine from the basal-bolus insulin therapy improves glycemic control in a patient with type 2 diabetes who had anti-insulin antibody
}

\author{
Hidekatsu Yanai · Taro Yoshimi • Hidetaka Hamasaki
}

Received: 8 May 2011 / Accepted: 23 August 2011 / Published online: 20 September 2011

(C) Research Society for Study of Diabetes in India 2011

\section{Dear Sir,}

Long-acting insulin analogs, the insulin glargine (glargine) and insulin detemir (detemir) induce a more prolonged, less peaked absorption profile compared with that of NPH insulin [1], and have been used in the basal-bolus insulin therapy for diabetic patients.

Here we report a type 2 diabetic patient who developed severe insulin resistance due to anti-insulin antibody after 2 years of the basal-bolus insulin therapy using insulin lispro (lispro) and detemir. Switching to three pre-meal injections of the newest rapid-acting insulin analog, insulin glulisine ameliorated hyperglycemia and decreased antiinsulin antibody level.

A 75-year-old man had been treated with the basal-bolus insulin therapy by five daily insulin injections: three injections of lispro before breakfast (10 units), lunch (6 units), and dinner (10 units) and two of detemir before breakfast (30 units) and at bedtime (50 units). His body weight was $73.4 \mathrm{~kg}$ and height $176.0 \mathrm{~cm}$, BMI $23.7 \mathrm{~kg} / \mathrm{m}^{2}$. Plasma glucose $(378 \mathrm{mg} / \mathrm{dl}), \mathrm{HbA}_{1 \mathrm{c}}$ [9.3\% (NGSP value)], and anti-insulin antibody $\left({ }^{125} \mathrm{I}\right.$-insulin binding rate, $35.9 \%$; normal range, $<0.4 \%$ ) levels was significantly elevated. Switching to the combination of glulisine and glargine brought down his blood glucose levels to $106-186 \mathrm{mg} / \mathrm{dl}$ by using 10,8 , and 8 units of glulisine before breakfast, lunch, and dinner, respectively, and 30 units of glargine at

\footnotetext{
H. Yanai $(\square) \cdot$ T. Yoshimi $\cdot$ H. Hamasaki

Department of Internal Medicine, Kohnodai Hospital, National Center for Global Health and Medicine,

1-7-1 Kohnodai,

Ichikawa, Chiba 272-8516, Japan

e-mail: dyanai@hospk.ncgm.go.jp
}

bedtime. Interestingly, further reduced dosing of glargine remarkably improved his glycemic control, and blood glucose levels were $88-180 \mathrm{mg} / \mathrm{dl}$ by using 8,10 , and 8 units of glulisine before breakfast, lunch, and dinner, respectively, and 10 units of glargine at bedtime. However, his anti-insulin antibody level was still high (37.5\%). Three pre-meal injections of glulisine (14 units before each meal) and discontinuation of glargine use finally controlled blood glucose $(151-195 \mathrm{mg} / \mathrm{dl})$ and decreased anti-insulin antibody level $\left({ }^{125}\right.$ I-insulin binding rate, $\left.25.1 \%\right)$.

Unlike other insulin analogs, glulisine allows for a viable drug product in the absence of hexamer-promoting zinc, which may provide immediate availability of glulisine at the injection site for absorption [2], while long-acting insulin analogs were designed to prolong absorption from subcutaneous tissue. The presence of insulin in a monomer form and the rapid absorption from the subcutaneous tissue may result in less anti-insulin antibody formation [3]. Therefore, switching to three pre-meal injections of glulisine from the basal-bolus insulin therapy may be effective in the treatment of patients with long-acting insulin analogs-mediated immunogenic insulin resistance.

\section{References}

1. Monami M, Marchionni N, Mannucci E. Long-acting insulin analogues vs. NPH human insulin in type 1 diabetes. A metaanalysis. Diabetes Obes Metab. 2009;11:372-8.

2. Becker RH, Frick AD. Clinical pharmacokinetics and pharmacodynamics of insulin glulisine. Clin Pharmacokinet. 2008;47:7-20.

3. Brange J, Owens DR, Kang S, Vølund A. Monomeric insulins and their experimental and clinical implications. Diabetes Care. 1990;13:923-54. 